\title{
Variation in Stomatal Characteristics of Bursera simaruba (L.) Sarg., a Dominant Tree Species of Tropical Hardwood Hammock Forest across a Habitat Gradient in the Florida Keys
}

\author{
Suresh C. Subedi1, Michael S. Ross ${ }^{2,3}$, Rosario Vidales², Jay P. Sah ${ }^{3}$, Leonel Sternberg1 \\ ${ }^{1}$ Biology Department, University of Miami, Coral Gables, FL, USA \\ ${ }^{2}$ Earth and Environment Department, Florida International University, Miami, FL, USA \\ ${ }^{3}$ Southeast Environmental Research Center, Florida International University, Miami, FL, USA \\ Email: subedi.suresh@gmail.com
}

How to cite this paper: Subedi, S.C., Ross, M.S., Vidales, R., Sah, J.P. and Sternberg, L. (2018) Variation in Stomatal Characteristics of Bursera simaruba (L.) Sarg., a Dominant Tree Species of Tropical Hardwood Hammock Forest across a Habitat Gradient in the Florida Keys. American Journal of Plant Sciences, 9, 2120-2139.

https://doi.org/10.4236/ajps.2018.910154

Received: March 15, 2018

Accepted: September 27, 2018

Published: September 30, 2018

Copyright $\odot 2018$ by authors and Scientific Research Publishing Inc. This work is licensed under the Creative Commons Attribution International License (CC BY 4.0).

http://creativecommons.org/licenses/by/4.0/

\begin{abstract}
Tree species in coastal forests may exhibit specialization or plasticity in coping with drought through changes in their stomatal morphology or activity, allowing for a balance between gas exchange and water loss in a periodically stressful environment. To examine these responses, we sought to answer two primary research questions: a) how is variation in $B$. simaruba's stomatal traits partitioned across hierarchical levels, i.e., site, tree, and leaf; and b) is variation in stomatal traits an integrated response to physiological stress expressed across the habitat gradient of Florida Keys forests? At eight sites distributed throughout the Keys, five leaves were collected from three mature trees for stomatal analysis. Leaf carbon stable isotope ratio $\left(\delta^{13} \mathrm{C}\right)$ was determined to infer the changes in water use efficiency caused by physiological stress experienced by each tree. The results showed that substantial proportions of the total variance in three traits (stomatal density, stomatal size, and $\delta^{13} \mathrm{C}$ ) were observed at all levels, suggesting that processes operating at each scale are important in determining trait values. A significant negative correlation between stomatal density and size across scales was observed. Path model analysis showed that environmental variables, distance to ground water and ground water salinity, affect leaf $\delta^{13} \mathrm{C}$ indirectly, via its effects on stomatal traits, not directly to leaf $\delta^{13} \mathrm{C}$. Therefore, the combination of small and densely distributed stomata seems to represent a strategy that allows $B$. simaruba to conserve water under conditions of physiological drought induced by either higher ground water salinity or flooding stress at very low elevation.
\end{abstract}




\section{Keywords}

Stomatal Density, Stomatal Size, $\delta^{13} \mathrm{C}$, Bursera simaruba, Dry Tropical Forest, Florida Keys

\section{Introduction}

The impacts of stress in plants growing in saline or flooded environments are similar to the ones faced by plants growing in dry environments [1], and are collectively referred to as physiological drought. Like drought stress, salt-induced stress occurs when water intake is limited, in this instance when salt concentrations in the soil solution rise above a critical level [2]. Both salt and drought stress lead to cellular dehydration, which causes osmotic stress [3]. The effects of osmotic stress can harm woody plants through cavitation of water columns within the xylem, or by toxicity of salts on biochemical processes [4]. Flooding stress likewise is detrimental to most terrestrial plants, resulting in dramatically reduced gas exchange between plants roots and the soil environment during flood events [5]. Physiological responses to flooding stress resemble those brought on by drought stress mainly due to root damage from root hypoxia, lowered root hydraulic conductivity, or accumulation of potentially toxic compounds [6].

Plant evolution in a temporally and spatially heterogeneous environment leads to one of two alternatives: specialization to a fraction of the environmental heterogeneity (evolutionary specialization); or generalized adaptation to a broad range of environments (i.e., phenotypic plasticity) [7] [8]. One way that plants may exhibit specialization or plasticity in dealing with drought is by changes in stomatal morphology or activity, allowing for a balance between gas exchange and water loss in stressful environments. Species adapted to a broad range of environments may respond to spatial and temporal environmental heterogeneity by plasticity in stomatal traits. In contrast, species or genotypes specialized in consistently dry environments are often less plastic in stomatal traits, as evolution of these traits is specific to those conditions [9]. Tendencies in stomatal architecture within a single tree species, where plasticity in stomatal density or size may be expressed across sites, among trees within a site, or even among leaves within a tree, depend on the scale at which the operative stress is expressed. Moreover, stomatal traits coupled with other physiological stresses will affect the discrimination against ${ }^{13} \mathrm{C}$ uptake during photosynthesis. The carbon fixed in the leaves of physiologically stressed plants including those suffering from salinity stress have been shown to be enriched in the heavier isotope ${ }^{13} \mathrm{C}$ compared with the lighter isotope ${ }^{12} \mathrm{C}[10]$. When plants are stressed, the rate of photosynthetic $\mathrm{CO}_{2}$ assimilation decreases due to reduced stomatal conductance and consequent restriction in the availability of $\mathrm{CO}_{2}$ for carboxylation. This will cause a lower discrimination against ${ }^{13} \mathrm{C}$ during the biochemical fixation of $\mathrm{CO}_{2}$ in the 
Calvin cycle [11]. Therefore, ${ }^{13} \mathrm{C} /{ }^{12} \mathrm{C}$ ratios (expressed as $\delta^{13} \mathrm{C}$, after standardization) may track the trajectories of stomatal density and size as well as other factors in response to hydrologic conditions.

Tropical dry forests of the Florida Keys occupy a wide range of physical settings, including flood-stressed, salt-stressed, and water-limited environments. Trees in these forests have two distinct sources of water: rainwater stored in an organic-rich soil layer and groundwater present at some depth in the bedrock. The organic soil layer is typically thin $(<30 \mathrm{~cm})$, causing trees to depend in varying degree on groundwater as their water source [12] [13]. Trees located at relatively low elevations have more access to the groundwater due to their proximity to the water table, while trees at higher elevations may become drought-stressed when soil water is exhausted. Although these forests, locally known as "hammocks", are infrequently flooded, those situated at elevations less than one meter above mean sea level may suffer flooding stress when high rainfall and/or high tides saturate the vadose zone for brief periods.

A third potential stressor is the salinity of the water available to Florida Keys trees, which is affected not only by distance to water table and source (rainfall or tides), but also by bedrock geology [14]. In the easternmost (Upper) Keys, even the water closest to the surface is brackish, because the coralline limestone that forms these islands is extremely permeable, allowing groundwater to mix freely with surrounding seawater [15]. In the lower Florida Keys, where a less permeable oolitic limestone overlies the coralline rock formation, a freshwater lens operating under Ghyben-Herzberg dynamics comprises the groundwater surface in some island interiors [16]. Geologic factors are therefore critical, as both the salinity of the groundwater and the proximity of tree roots to it may determine the magnitude of water stress and the nature of plant response.

A hypothetical alignment of physiologic stresses and leaf characteristics is illustrated graphically for a single mesophytic tree species in the Florida Keys (Figure 1). The independent curve of stress with distance to the water table is concave, with highest levels close to the water table and far above it, and lowest stress at intermediate elevations (Figure 1). In contrast, stress increases monotonically with increasing salinity, all else being equal. We expect the response in leaf $\delta^{13} \mathrm{C}$, as a direct reflection of plant stress, to follow suit, varying with both the salinity of the groundwater table and its distance below the soil surface.

Some studies have argued that an increase in stress caused by drought or salinity causes plants to produce fewer and larger stomates to minimize their water loss by transpiration under dry or saline conditions [4] [17] [18] [19] [20]. In contrast, other studies have shown that drought stress and arid climatic conditions causes an increase in stomatal density and a decrease in stomatal size because plants with larger stomata are slower to close and demonstrate a greater potential for hydraulic dysfunction under drought [21] [22] [23]. Based on these two views, the causal relationships (arrows) between stomatal traits, environmental variables (ground water salinity and distance to ground water), and 


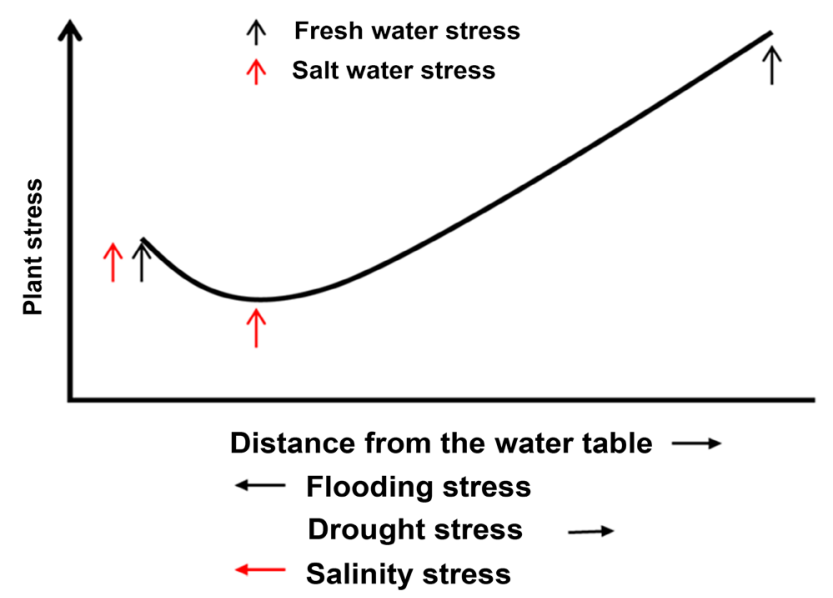

Figure 1. Diagram showing plant stress in response to distance from the ground water table. Red and black arrows shows the direction of plant stress increases due to freshwater stress and saltwater stress, respectively.

leaf $\delta^{13} \mathrm{C}$ are illustrated in a path model for a single mesophytic tree species in the Florida Keys (Figure 2). If an increase in physiological stress is associated with fewer and larger stomates, leaf $\delta^{13} \mathrm{C}$ and stomatal density are expected to exhibit a negative correlation. On the other hand, if an increase in physiological stress is associated with many and smaller stomates, leaf $\delta^{13} \mathrm{C}$ and stomatal density are expected to exhibit a linear positive correlation.

Most studies that have explored stomatal variation in nature have used controlled experiments, or comparisons among closely or distantly related species. This study takes a different approach by addressing hierarchical issues of landscape-scale stomatal trait variance in a species distributed widely across a dry subtropical forest, where local populations are found in a broad range of environments. In dry-tropical forest, where our understanding of stomatal trait variation is limited, physiological traits including stomatal traits are influenced by different processes operating across distinct spatial scales ranging from regional environmental factors such as climate, geology, elevation, groundwater salinity, to localized factors such as light and soil environment [24]. Identifying which scales cause the most variation in traits provides important information regarding the patterns and processes that are ecologically most critical [25]. For example, the primary factors that drive trait variation across the sites may include topography, disturbance, edaphic, and hydrological factors, while factors that drive trait variation within a population (site) are mainly due to phenotypic plasticity in response to micro-environmental heterogeneity.

In this paper, we examine stomatal size and density in Bursera simaruba, a common tree species in tropical dry forests of the Florida Keys. Sampling leaves from eight forests, we determined how small differences in environmental conditions such as elevation, geology, and groundwater salinity affected both stomatal structure and physiological stress, as reflected by carbon isotope ratios. In the process, we quantified variance in stomatal traits across a hierarchy of scales: 


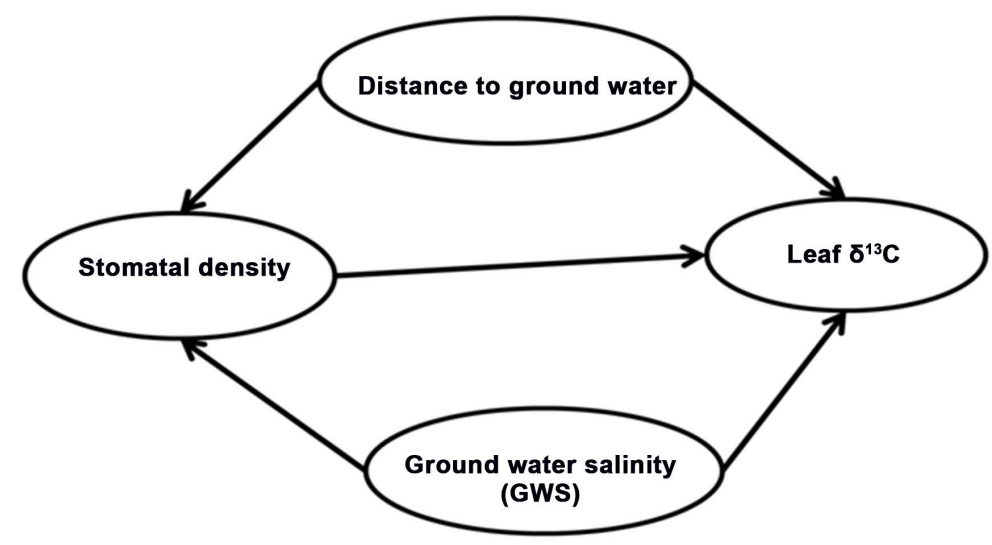

Figure 2. Path model showing the causal relationships (arrows) between stomatal traits, environmental variables (ground water salinity and distance to ground water, and leaf $\delta^{13} \mathrm{C}$. Stomatal traits is expected to have effect in $\delta^{13} \mathrm{C}$ (unknown, either positive or negative); Ground water salinity can have effect on both stomatal traits (positive or negative) and $\delta^{13} \mathrm{C}$ (negative), while proximity to ground water is directly related to trees availability of freshwater so it might have effect on both $\delta^{13} \mathrm{C}$ (positive) and stomatal traits (positive or negative).

site, tree, and leaf levels. We sought to answer two questions: a) how is the variance in stomatal traits (size and density) partitioned across the hierarchical levels? and b) at the site level, does variation in B. simaruba (L.) Sarg. stomatal traits reflect physiological stress expressed across the habitat gradient of Florida Keys forests?

\section{Materials and Methods}

The Florida Keys are a $210 \mathrm{~km}$ chain of islands running southwest from Soldier Key $\left(25^{\circ} 36^{\prime} \mathrm{N}, 80^{\circ} 10^{\prime} \mathrm{W}\right)$, near the Florida mainland, to Key West $\left(24^{\circ} 33^{\prime} \mathrm{N}\right.$, $\left.81^{\circ} 49^{\prime} \mathrm{W}\right)$. Conditions become progressively drier and warmer with increasing distance from the mainland. For instance, mean annual rainfall and temperature are $1200 \mathrm{~mm} \mathrm{~m}$ and $25.1^{\circ} \mathrm{C}$ at Tavernier in the Upper Keys and $1000 \mathrm{~mm}$ and $25.4^{\circ} \mathrm{C}$ at Key West in the Lower Keys [26]. The highest elevation is only $5.5 \mathrm{~m}$ above the sea level, while most of the land area is below $2 \mathrm{~m}$.

Our study of stomatal characteristics was initiated in 2014, using B. simaruba as a focal species due to its local abundance and wide distribution within hammocks of the study area. Eight study sites were chosen: three in the lower Keys, two in the middle Keys, and three in the upper Keys (Figure 3). Each of these sites contained a well from which ground water salinity and distance to water table had been determined at monthly intervals during 1989-1992 [26]. While subsequent research has shown some increases in groundwater salinity in Keys natural areas since 1992 [13], these changes have been small, especially in the interior locations where most of the study sites were located.

The study of leaf characteristics began with collection of newly matured, healthy B. simaruba leaves from all eight sites during July-October 2014. To 


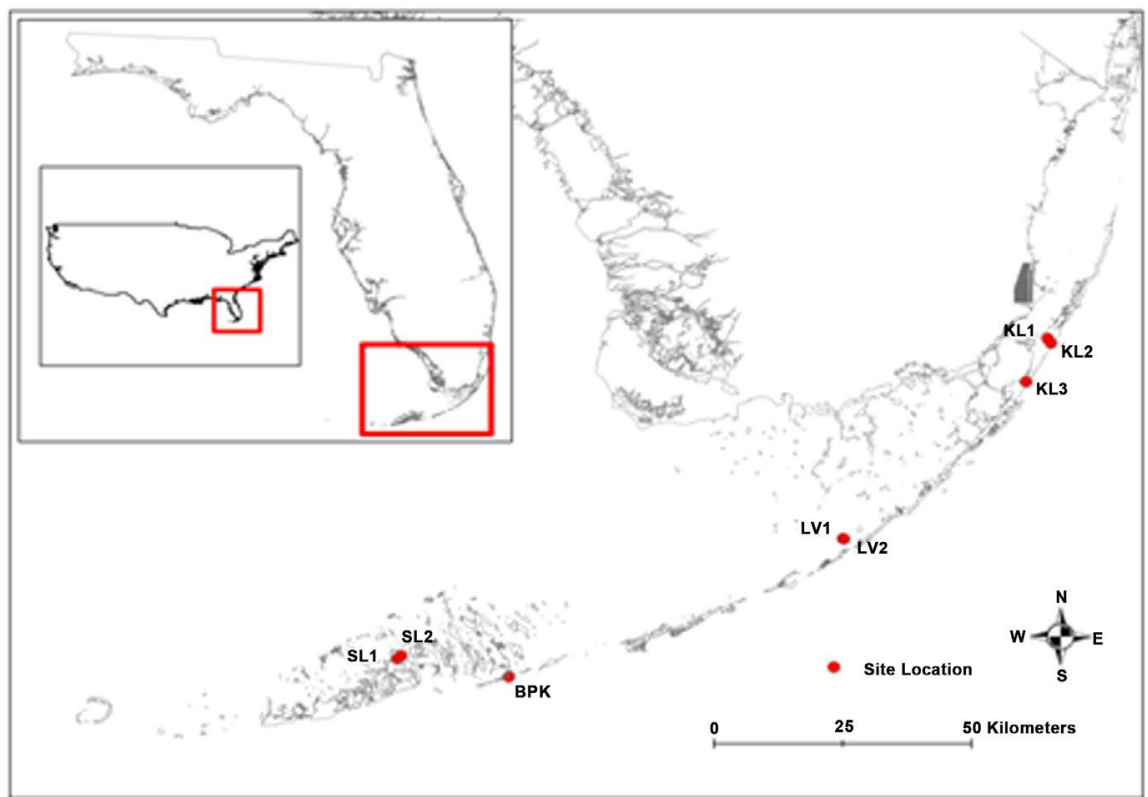

Figure 3. Map showing study locations.

control for trait variation within the canopy, we collected only leaves from the outer canopy, fully exposed to sun. Since all data were collected during one wet season (July-October), trait variation among seasons was minimized. Similarly, variation associated with leaf age was minimized by collecting only the youngest fully expanded leaves. Three trees per site were selected randomly, and five leaves were collected from each tree. Altogether, 120 leaves were sampled from 24 trees.

Assessment of stomatal density and size involved the construction of leaf imprints through application of clear nail polish to the leaf, after which the imprints were lifted off by tape and placed on a slide [27]. Digital images of three randomly selected views of each leaf were taken under a compound microscope. Stomatal density and size were analyzed in ImageJ [28]. Stomatal density was determined from total counts within areas of $0.275 \mathrm{~mm}^{2}$ at $160 \mathrm{X}$ magnification, which were converted to number of stomata per $\mathrm{mm}^{2}$ for analysis. A total of 345 captured fields of view were used. Imprint images that had visible leaf veins, which lacked stomata, required a correction to the total area viewed [29]. Using the polygon-drawing tool in ImageJ, veins were digitized, and their area calculated and subtracted from the total observed grid area. Stomatal size was represented by measures of guard cell length i.e., the length between the junctions of the guard cells at each end of the stomata [30]; this is a measure of the maximum potential opening of the stomatal pore rather than the apparent aperture [31]. Stomatal length was measured using a compound microscope at 1000X magnification.

${ }^{13} \mathrm{C}$ content of leaves was determined with data expressed in "delta" notation $\left(\delta^{13} \mathrm{C}\right)$ as [32]:

$$
\delta^{13} C=[(\text { Rsample } / \text { Rstandard })-1] \times 1000
$$


where, $\mathrm{R}_{\text {sample }}$ and $\mathrm{R}_{\text {standard }}$ are the ratios ${ }^{13} \mathrm{C}:{ }^{12} \mathrm{C}$ of the sample and standard, respectively, and $R_{\text {standard }}$ for carbon is of marine fossils of the Pee Dee Belemnite. Sample processing was done by drying at $65^{\circ} \mathrm{C}$ to constant weight, grinding the samples to a fine powder, and combusting $2-3 \mathrm{mg}$ subsamples in an elemental analyzer (Carlo Erba) coupled to an isotope ratio mass spectrometer (IRMS Delta Plus, Finnigan Mat, San Jose, CA, USA) operating in the continuous flow mode at Southeast Environmental Research Center Stable Isotope Laboratory, Florida International University, Miami, USA.

We used a linear mixed model to partition the variance in stomatal traits and leaf $\delta^{13} \mathrm{C}$ across sites, among trees within a site, and among leaves within a tree. Mixed models that specified this nested structure were fitted using the 'varcomp" function in 'nlme' library of R [33] with restricted maximum likelihood estimation. The code used in $\mathrm{R}$ to calculate the variance partitioning of the stomatal density trait across the nested scales for the full model was:

$\operatorname{varcomp}(\operatorname{lme}($ stomatal density 1 ,random $=1 \mid$ Site/Tree/Leaf) $)$

The same model was applied to stomatal size and leaf $\delta^{13} \mathrm{C}$. The variance attributable to each hierarchical level was expressed as a percentage of the total variance. We also plotted and calculated the linear correlations between stomatal traits and leaf $\delta^{13} \mathrm{C}$.

Since carbon isotope ratios may be influenced by all the measured parameters (stomatal traits and environmental variables), we used path analysis to model direct and indirect effects of stomatal density, proximity to ground water, and GWS on dependent variable $\left(\delta^{13} \mathrm{C}\right)$. The correlations among predictor variables (stomatal traits, GWS, and proximity to the ground water), may affect the regression models by inflating the standard errors of estimate and destabilizing the regression coefficients. The independent variables were also tested for colinearity. We modeled the causal effects across the network and used path coefficients (standardized partial regression coefficients) to assess the relative strength of direct and indirect causal paths on the dependent variable. We calculated indirect effects of an independent variable as a sum of products of path coefficients along all paths leading to a carbon isotope ratio, dependent variable [34]. Both direct and indirect effects were summed to calculate the total effects of each variable in the model on the plant stress (leaf $\delta^{13} \mathrm{C}$ ).

\section{Results}

Two critical environmental variables, i.e., distance to water table and ground water salinity) varied by site and region (Lower, Middle, and Upper Keys, Table 1). Ground water salinity, which ranged from 2 to $24 \%$, was maximum in Key Largo $(23.4 \%, \mathrm{KL} 3)$ and lowest in Sugarloaf Key $(2.8 \%$, SL2). Similarly, distance to the water table ranged from $66 \mathrm{~cm}$ (SL1) to $380 \mathrm{~cm}$ (KL3) (Table 1).

The decomposition of the total variance in stomatal density, stomatal size, and leaf $\delta^{13} \mathrm{C}$ among the hierarchical levels is shown in Table 2. For stomatal density, 
Table 1. Sites with mean ground water salinity (GWS), ground elevation, and soil depth. Site ID's: KL = Key Largo, LV = Lignum vitae Key, BPK = Big Pine Key, SL = Sugarloaf Key.

\begin{tabular}{ccccc}
\hline Site & $\begin{array}{c}\text { Average GWS } \\
(\%)\end{array}$ & $\begin{array}{c}\text { Average distance to water } \\
\text { table }(\mathrm{cm})\end{array}$ & $\begin{array}{c}\text { Average elevation } \\
(\mathrm{cm})\end{array}$ & Soil depth $(\mathrm{cm})$ \\
\hline KL1 & 3.80 & 47.29 & 69.71 & 12 \\
KL2 & 15.25 & 121.26 & 156.48 & 10 \\
KL3 & 23.44 & 328.46 & 379.54 & 20.4 \\
LV1 & 20.42 & 258.48 & 291.27 & 10.2 \\
LV2 & 13.83 & 49.07 & 73.62 & 10.3 \\
SL1 & 9.81 & 38.23 & 66.1 & 12.7 \\
SL2 & 2.78 & 69.81 & 78.60 & 15.2 \\
BPK & 4.65 & 54.27 & 79.68 & 15.3 \\
\hline
\end{tabular}

Table 2. Decomposition of the total variation in stomatal density, stomatal length, and leaf $\delta^{13} \mathrm{C}$ traits across three hierarchical levels (site, tree, and leaf).

\begin{tabular}{cccc}
\hline Groups & Stomatal density (\%) & Stomatal size (\%) & Leaf $\delta^{13} \mathrm{C}(\%)$ \\
\hline Site & 41 & 12 & 9 \\
Tree & 30 & 17 & 5 \\
Leaf & 23 & 61 & 76 \\
Residual & 6 & 10 & 9 \\
\hline
\end{tabular}

the proportion of the total variance was well distributed across the three scales, with the highest proportion at the site level $(41 \%)$ and the lowest percentage at the leaf level (21\%). However, the bulk of the variation in both stomatal size and leaf $\delta^{13} \mathrm{C}$ was found at the leaf level (61\% and $76 \%$, respectively), while variation at tree and site levels was very low (12\% and 9\%, respectively).

Stomatal density ranged from 350 to $1017 \mathrm{~mm}^{-2}$, and stomatal size i.e., length ranged from 14 to $32 \mu \mathrm{m}$. Despite considerable variation within sites, stomatal density exhibited an inverse relationship (negatively correlation) with stomatal size at the site level $(\mathrm{r}=-0.64, \mathrm{p}<0.05$, Figure 4$)$.

Leaf $\delta^{13} \mathrm{C}$ ranged from -33.13 to -25.12 . Leaves in three upper Keys locations-elevated sites with ground surface well above a brackish groundwater table-were most enriched in the heavy carbon isotope (high $\delta^{13} \mathrm{C}$ ), indicating relatively high stress; in turn, lower Keys sites with fresher groundwater showed more depleted carbon signatures. Leaf $\delta^{13} \mathrm{C}$ was positively correlated with stomatal density $(\mathrm{r}=0.61, \mathrm{p}=0.02$; Figure 5$)$.

Path analysis showed that change in distance to ground water and GWS led to an increase in stomatal traits (Figure 6). Stomatal traits had, in turn, a direct effect on the leaf $\delta^{13} \mathrm{C}$, stomatal density leading to significant increase in $\delta^{13} \mathrm{C}$ (Table 3). More importantly, environmental variables (distance to ground water and GWS) affected leaf $\delta^{13} \mathrm{C}$ indirectly, via its effects on stomatal traits, not directly on $\delta^{13} \mathrm{C}$ (Table 3 ). 


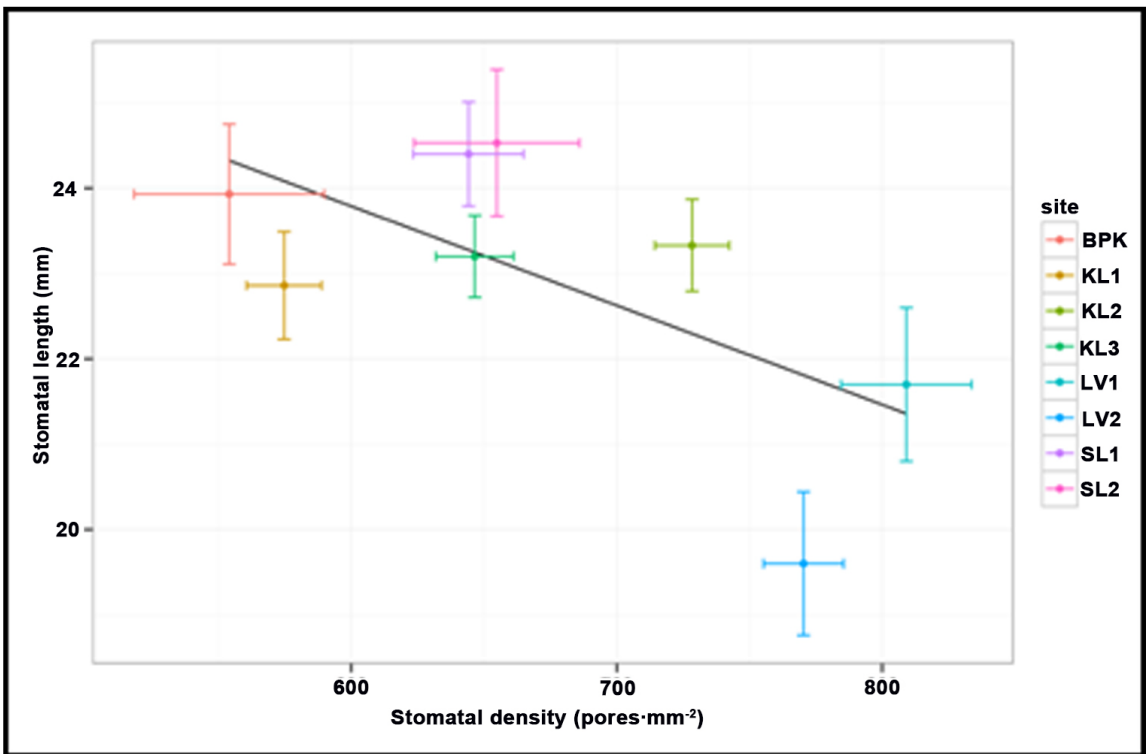

Figure 4. Relationship between stomatal density and stomatal length. The regression line is fit to site level means. Error bars represent standard errors of mean ( $\mathrm{n}=15$ for each site, $\mathrm{r}=-0.64, \mathrm{p}<0.05)$.

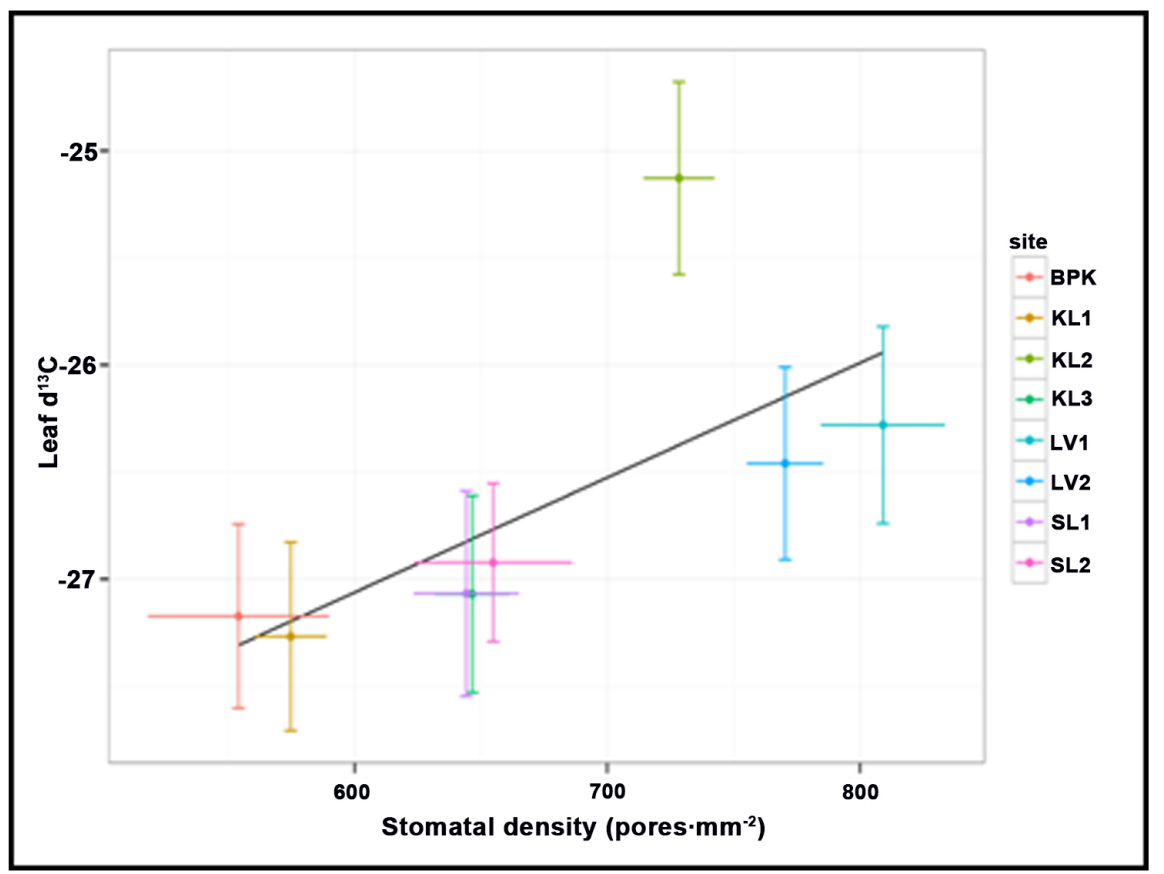

Figure 5. Relationship between stomatal density and leaf $\delta^{13} \mathrm{C}$. The regression line is fit to site level means. Error bars represent standard errors of mean $(\mathrm{n}=15$ for each site, $\mathrm{r}=$ $0.61, \mathrm{p}=0.02)$.

\section{Discussion}

\subsection{Stomatal Trait Partitioning across Scales}

Variance in leaf traits was observed at all levels, suggesting that processes operating at all three scales are important in determining trait values. Site level 


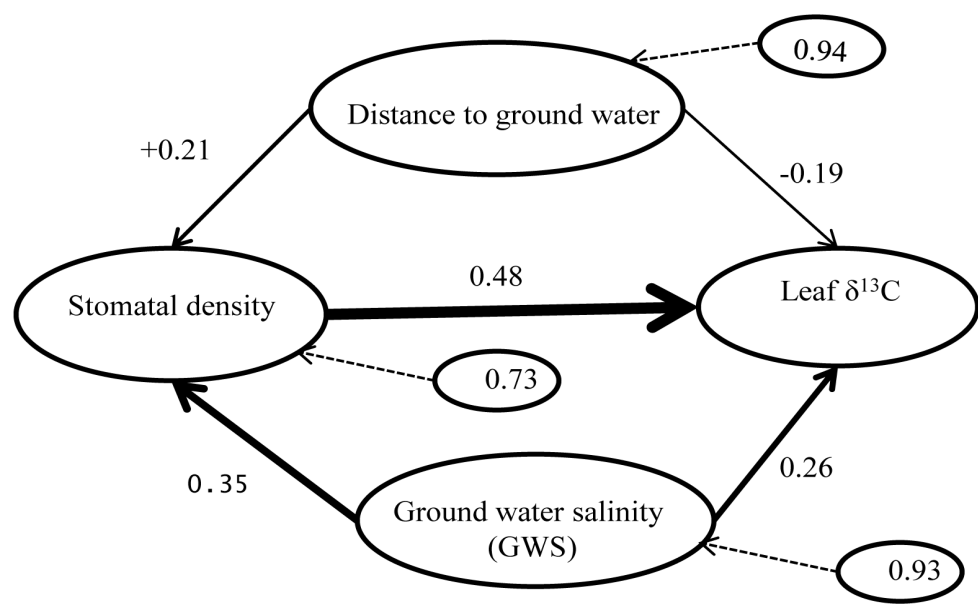

Figure 6. Path model showing the causal relationships (arrows) between environmental variables (ground water salinity, distance to ground water), stomatal trait (stomatal density), and leaf $\delta^{13} \mathrm{C}$ for $B$. simaruba in seasonally dry forest in Florida Keys. The thickness of lines indicates relative strength of significant correlations. Dashed lines showing the unexplained variation of the regression model $((\sqrt{ }(1-R 2))$ Distance to ground water, GWS were log-transformed to comply with linear models assumptions. Positive and negative values in the figure indicate the negative and positive relationship, respectively.

Table 3. Effect of coefficients for variables affecting leaf leaf $\delta^{13} \mathrm{C}$ in path analysis for $B$. simaruba across the habitat gradient in Florida Keys. Significant results $(\mathrm{p}<0.05)$ are presented in bold.

\begin{tabular}{cccc}
\hline Variable & Direct effect & Indirect effect & Total effect \\
\hline Ground water salinity (GWS) & 0.26 & $\mathbf{0 . 4 3}$ & $\mathbf{0 . 6 9}$ \\
Distance to GW & -0.19 & -0.30 & -0.49 \\
Stomatal density & $\mathbf{0 . 4 8}$ & Not modeled & $\mathbf{0 . 4 8}$ \\
\hline
\end{tabular}

variation might arise from adaptations to environmental differences across the study area. Dry tropical forests in the Florida Keys are water-limited ecosystems in which trees go through a long (usually more than five months) dry period each year. Sites vary in freshwater availability, depending on factors such as soil depth, geographical location, proximity to the water table, and ground water salinity (Table 1). The conceptual models presented in Figure 1 and Figure 2 outline our expectations if trait variation is driven primarily by broad differences among sites in environmental characteristics (distance to water table and ground water salinity. Depending on their strength, sources of within-stand and within-tree variation are likely to obscure these relationships.

Though we attempted to minimize this source of variation by sampling fully developed and healthy leaves from the upper canopy (dark green with no visible damage due to herbivory or disease), a large amount of trait variation was observed at the leaf level for all three traits ( $>21 \%$, Table 2$)$. The origin of trait variation at the leaf level may be biological or physical. In the first category, the 
phenomenon of apical dominance arises out of interference competition. The apical meristem produces auxin, a growth substance that diffuses downward through tissue and inhibits the growth of lateral meristems. During branching, the apical meristems of a plant compete with one another for resources (light, water, nutrients) [35]. Height growth in fast-growing trees such as B. simaruba may be effectuated by a few meristems, which suppress the development and elongation of lateral shoots. Therefore, variation in leaf traits within a tree might be expressions of internal competition between branches for limited resources. Likewise, all portions of the crown do not experience the same environment, especially with respect to access to sunlight. Branch shading within a crown is likely to create asymmetric within-canopy competition for resources between individual branches. In addition, leaves of tall trees like B. simaruba are susceptible to occasional airborne doses of salt spray brought by wind and wave activities in coastal environments, and salt deposition may be unevenly distributed within the canopy. The effect of salt spray is even more pronounced where water availability is limited [36], as it is in the Florida Keys' forests. Salt deposition on leaves during and/or after leaf development may create physiological stress, and contribute to variation in leaf structure or function.

Our analysis of variance partitioning suggests that the leaf traits we examined in B. simaruba differed in their responses to short-term or fine-scale environmental variation; the overwhelming concentration of variance in stomatal size and $\delta^{13} \mathrm{C}$ at the leaf level contrasted sharply with the large proportion of variance in stomatal density found at the site level. Variation in stomatal traits among trees within a site, and among leaves within a tree is likely to be affected by both environmental and biological factors. Within-site variability in plant traits may result from microtopographic differences. In Florida Keys' dry tropical forests, physical and chemical erosion has produced a rough karst surface characterized by peaks and valleys that can vary by decimeters to meters over very short distances. On well-drained sites in the lower Keys, trees at lower elevations may be favored by better access to fresh groundwater than those on higher ground. Biological factors such as neighbor effects are also likely to come into play at this level, due to competition among trees for resources in limited supply (water, light, nutrients). Similarly, within-site variation may also occur due to genetic variation among the individual trees. B. simaruba seeds are generally dispersed by birds, which are likely to transport fruits to nearby islands, resulting in mixing of the seed pool, while allowing for genetic segregation among distant population clusters. These patterns point to differences in plasticity among traits, as discussed by other authors (e.g., Franks et al., 2014). The large proportion of variance in stomatal density among populations at the site level may indicate that variation in this trait may result from a long-time selective pressure in environments with different water availability [37] [38], and therefore might comprise adaptive responses to persistent differences in freshwater availability across sites. In contrast, variation in stomatal size and leaf $\delta^{13} \mathrm{C}$ may be reflective of plastic responses to microenvironment. For instance, leaf $\delta^{13} \mathrm{C}$ is considered a short-term 
response to the current environment, as it carries a temporally integrated signature of foliar photosynthesis and stomatal conductance [39]. Similarly, in a shade-house experiment, Aasamaa et al. (2001) observed significant changes in stomatal size of tree species subjected to water stress over short periods, while stomatal density varied only slightly among the same trees. Therefore, changes in stomatal size and leaf $\delta^{13} \mathrm{C}$ in $B$. simaruba seem to be short-term plastic responses to changes in microenvironment expected at the tree or leaf levels, while change in stomatal density is a response to relatively fixed, macro-scale environmental variation [40] [41] [42].

\subsection{Stomatal Traits and Plant Stress}

A strong inverse relationship between stomatal density and size was observed in this study (Figure 4) and several others above. This relationship seems to be driven by two factors: ontogenetic process and leaf size [43]. Stomatal density may be affected by ontogenetic process causing cell expansion or shrinkage during leaf development stages [44]. For instance, increases in leaf size with increasing moisture and/or nutrient availability [45] [46] may cause decreases in stomatal density due to increases in the size of both epidermal and stomatal guard cells. In contrast, drought and high irradiance can reduce leaf area [47] [48], causing stomata to be packed more densely. Therefore, a high stomatal density could be the outcome of the formation of a larger number of stomatal cells in the epidermis either during leaf development, or of the failure of the leaf to expand fully, leaving a fixed number of stomates within a smaller leaf. Alternatively, low stomatal density might be the result of rapid cell growth, which would increase the distance between stomates and decrease their density, or a product of low stomate formation. In our study, total leaf size was not measured on the same leaves analyzed for stomatal traits. However, in a parallel study at the same sites, we did determine leaf area on 3 - 5 leaves from 1 - 3 B. simaruba trees per plot [49], and no significant difference in leaf size was observed among sites $(\mathrm{p}=0.54)$. This suggests that the inverse relationship between stomatal density and size found in this study is likely not the result of shrinkage of the leaves, and is more likely the result of an ontogenetic process.

The inverse relationship between stomatal density and stomatal size is generally explained as a coordinated strategy in the plant's management of stomatal conductance and transpiration under stressful conditions [4] [21] [50] [51]. Our results might indicate that an increase in physiological stress is associated with many and smaller stomates, as stomatal density exhibited a direct effect on the leaf $\delta^{13} \mathrm{C}$ (Table 3, Figure 6). However, environmental variables measured in this study (distance to ground water and GWS) affect leaf $\delta^{13} \mathrm{C}$ indirectly by altering stomatal traits. The rationale often proposed for such results is that plants with large stomates are less proficient at regulating stomatal closure and opening, and hence respond poorly to drought [22] [52] [53], while being well suited for more favorable moisture conditions [22]. This result differs from communi- 
ty-level studies [49] [54] which shows that elevated productive sites in areas of high GWS are the most productive, and have the lowest community-weighted $\delta^{13} \mathrm{C}$. However, B. simaruba responded differently than most other species in the community. Considering the nature of the karst substrate and very thin soil layer in South Florida and Florida Keys, it is expected that the majority of hammock tree species might use groundwater [12], particularly by tall canopy trees. In addition, although species in hardwood hammock community in South Florida have little ability to tolerate salt stress, they may vary among themselves in their responses to salt and/or drought stress. It turned out that majority of tree species (20 out of 28 species) in productive sites (North Key Largo) had relatively low $\delta^{13} \mathrm{C}(<-29.16)$; while all the canopy trees $(7$ species) greater than $12 \mathrm{~m}$ had higher $\delta^{13} \mathrm{C}(-26.9$ to -28.65$)$ (Supplementary Table 1$)$. In this case, canopy species with higher growth rate [49] also had higher $\delta^{13} \mathrm{C}$. Therefore, any increase of salt levels in GW may have caused more stress in the tallest trees which may be overcome by other factors, such as an increase in nutrient availability from the groundwater source.

Further support for this view may be drawn from our observations of high stomatal density at very low elevations (short distance from ground water table) and increases with increase in ground water salinity (Figure 7). Hammock forests at very low elevations in coastal environments likely suffer flooding stress during high rainfall and/or high tides that inundate the surface. The observed linear increase in stomatal density and decrease in stomatal size with increasing ground water salinity might be associated with salt stress. Furthermore, the observed decrease in stomatal density and increase in stomatal size with increasing distance from the ground water table in areas of low ground water salinity (Figure 7) may indicate that trees at higher elevations do not suffer greatly from drought stress. Higher elevation sites are characterized by deeper soils, which might store rainwater for more persistent use by trees. Therefore, it can be argued that trees at high elevation in Florida Keys benefit from being located at high elevation with more access to freshwater compared to trees at lower elevations.

Studies that reported results contrasting to ours were based mostly on comparisons among species or functional groups, rather than variation within individual species. For instance, salt-tolerant mangrove species were reported to have fewer and larger stomates than freshwater species [4], which could be due to evolutionary specialization to a consistently stressful environment. Studies have shown that species specialized in less favorable environments often lack plasticity [55]. Therefore, a wide variation in stomatal traits across the habitat gradient is likely to be the result of adaptive plasticity across the heterogeneous environments.

B. simaruba, the subject of our investigation, is a freshwater species with a wide geographical distribution across the environmental gradient, but possibly with limited ability to tolerate salt stress, as observed in other hammock species 


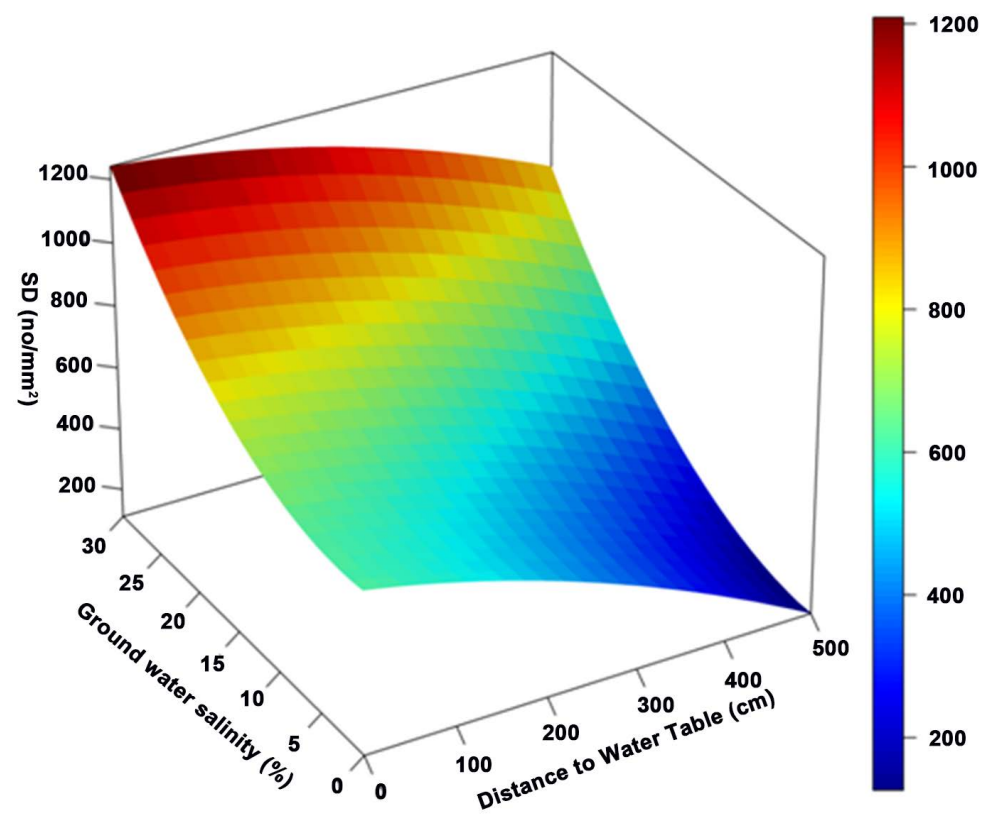

(a)

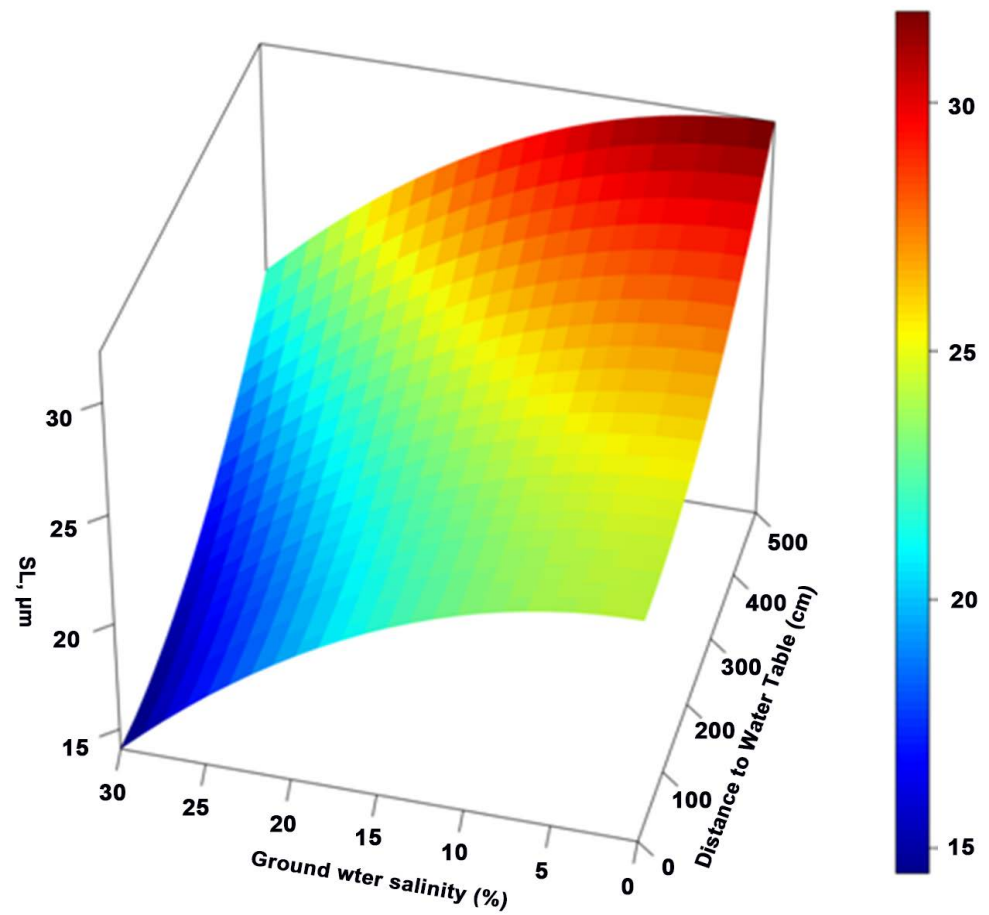

(b)

Figure 7. 3-D Surface plot resulted from quadratic fit (second order) by using multiple regression showing stomatal density $\left(\mathrm{SD}\right.$, no $\left.\mathrm{mm}^{-2}\right)$, leftand stomatal length $(\mathrm{SL}, \mu \mathrm{m})$, rightas a function of distance to water table and ground water salinity (GWS).

[56]. It is a tall canopy tree, often reaching $15 \mathrm{~m}$, with high growth rate, very low wood density $\left(0.30 \mathrm{~g} / \mathrm{cm}^{3}\right)$, and high specific leaf area $\left(300 \mathrm{~cm}^{2} / \mathrm{g}\right)$. Though trees growing on surfaces in close proximity to brackish groundwater did exhibit 
some evidence of hydraulic stress, a parallel study at the same sites showed a non-significant structural differences (height, crown dimensions, diameter at breast height, leaf area) among $B$. simaruba populations [49]. Therefore, regardless of any habitat differences that might affect resource availability, all sampled populations had sufficient hydraulic and stomatal conductance to enable good growth. Canopy species in dry habitats are known to be opportunistic, capable of high stomatal conductance and photosynthetic capacity that enables rapid growth during short periods of water availability [22]. $\delta^{13} \mathrm{C}$ can be used as an indirect measure of water use efficiency and stomatal conductance during drought stress [18]. It seems that a trade-off between many and small stomates in stressful environments, and large and few stomates in less stressful environments may be a strategy pertinent to rapidly growing canopy species across the environmental gradient. Small stomates have the ability to open and close rapidly, and their association with high stomatal density may provide the capacity for rapid increases in leaf stomatal conductance during favorable conditions [22].

\section{Conclusion}

Our results suggest that stomatal characteristics may be viewed as adaptive traits that play an important role in water relations for $B$. simaruba populations. The observed variation in stomatal size and density in $B$. simaruba individuals could determine the capacity of the trees to adapt to various levels of physiological stress. Stomatal density and size of $B$. simaruba trees may change with the level of physiological stress, as expected in plants with the capacity for phenotypic plasticity in heterogeneous environments [57]. This study suggests that B. simaruba has the ability to alter its stomatal traits in response to environmental variation, as a result of plasticity under drought conditions. Production of the combination of small and densely distributed stomates seems to represent a strategy that allows $B$. simaruba to conserve water under conditions of periodic physiological drought by maintaining stomatal control. This variability may be called upon as the coastal forests that it inhabits are exposed to the higher salinity and locally droughty conditions that will accompany global warming and sea-level rise. Furthermore, repeating this analytical approach on individuals subjected to serial changes in drought intensity may confirm this pattern.

\section{Acknowledgements}

The authors thank to Leah Ramnath for her help during the field and laboratory work. The authors also thank to Dr. Jennifer Richards for important insight at the beginning of the project, and for providing lab facilities. S.S. was partially supported by graduate student research project funded from the International Center for Tropical Botany (ICTB).

\section{Conflicts of Interest}

The authors declare no conflicts of interest regarding the publication of this paper. 


\section{References}

[1] Carrow, R.N. and Duncan, R.R. (1998) Salt-Affected Turfgrass Sites: Assessment and Management. John Wiley and Sons.

[2] Chartzoulakis, K., et al. (2002) Effects of $\mathrm{NaCl}$ Salinity on Growth, Ion Content and CO 2 Assimilation Rate of Six Olive Cultivars. Scientia Horticulturae, 96, 235-247. https://doi.org/10.1016/S0304-4238(02)00067-5

[3] Bartels, D. and Sunkar, R. (2005) Drought and Salt Tolerance in Plants. Critical Reviews in Plant Sciences, 24, 23-58. https://doi.org/10.1080/07352680590910410

[4] Sternberg, L.D.S.L. and Manganiello, L.M. (2014) Stomatal Pore Size and Density in Mangrove Leaves and Artificial Leaves: Effects on Leaf Water Isotopic Enrichment during Transpiration. Functional Plant Biology, 41, 648-658.

https://doi.org/10.1071/FP13235

[5] Ewe, S.M.L. and Sternberg, L.D.S.L. (2003) Seasonal Gas Exchange Characteristics of Schinus terebinthifolius in a Native and Disturbed Upland Community in Everglades National Park, Florida. Forest Ecology and Management, 179, 27-36. https://doi.org/10.1016/S0378-1127(02)00531-5

[6] Kozlowski, T.T. (2000) Responses of Woody Plants to Human-Induced Environmental Stresses: Issues, Problems, and Strategies for Alleviating Stress. Critical Reviews in Plant Sciences, 91-170. https://doi.org/10.1080/07352680091139196

[7] Van Kleunen, M. and Fisher, M. (2001) Adaptive Evolution of Plastic Foraging Responses in a Clonal Plant. Ecology, 82, 3309-3319. https://doi.org/10.1890/0012-9658(2001)082[3309:AEOPFR]2.0.CO;2

[8] Agrawal, A.A. (2001) Phenotypic Plasticity in the Interactions and Evolution of Species. Science (New York, N.Y.), 294, 321-326.

https://doi.org/10.1126/science.1060701

[9] Valladares, F., et al. (2000) Low Leaf-Level Response to Light and Nutrients in Mediterranean Evergreen Oaks: A Conservative Resource-Use Strategy? New Phytologist, 148, 79-91. https://doi.org/10.1046/j.1469-8137.2000.00737.x

[10] Farquhar, G.D., et al. (1982) On the Relationship between Carbon Isotope Discrimination and the Intercellular Carbon Dioxide Concentration in Leaves. Functional Plant Biology, 9, 121-137.

[11] Wang, C., et al. (2012) Systematic Comparison of C3 and C4 Plants Based on Metabolic Network Analysis. BMC Systems Biology, 6.

[12] Ish-Shalom, N., et al. (1992) Water Utilization of Tropical Hardwood Hammocks of the Lower Florida Keys. Oecologia, 92, 108-112.

https://doi.org/10.1007/BF00317270

[13] Ogurcak, D. (2016) The Effect of Disturbance and Freshwater Availability on Lower Florida Keys' Coastal Forest Dynamics.

[14] Halley, R.B., et al. (1997) Geology and Hydrogeology of the Florida Keys, Geology and Hydrology of Carbonate Islands. Developments in Sedimentology, 217-248.

[15] Lapointe, B.E., et al. (1990) Nutrient Couplings between On-Site Sewage Disposal Systems, Groundwaters, and Nearshore Surface Waters of the Florida Keys. Biogeochemistry, 10, 289-307. https://doi.org/10.1007/BF00003149

[16] Langevin, C.D., Stewart, M.T. and Beaudoin, C.M. (1998) Effects of Sea Water Canals on Fresh Water Resources: An Example from Big Pine Key, Florida. Ground Water, 36, 503-513. https://doi.org/10.1111/j.1745-6584.1998.tb02822.x

[17] Woodward, F.I. and Kelley, C.K. (1995) The Influence of $\mathrm{CO}_{2}$ Concentration on 
Stomatal Density. New Phytologist, 131, 311-327.

https://doi.org/10.1111/j.1469-8137.1995.tb03067.x

[18] Franks, P.J. and Beerling, D.J. (2009) Maximum Leaf Conductance Driven by $\mathrm{CO}_{2}$ Effects on Stomatal Size and Density over Geologic Time. Proceedings of the National Academy of Sciences of the United States of America, 106, 10343-10347. https://doi.org/10.1073/pnas.0904209106

[19] Barbieri, G., et al. (2012) Stomatal Density and Metabolic Determinants Mediate Salt Stress Adaptation and Water Use Efficiency in Basil (Ocimum basilicum L.). Journal of Plant Physiology, 169, 1737-1746. https://doi.org/10.1016/j.jplph.2012.07.001

[20] Orsini, F., Alnayef, M., Bona, S., Maggio, A. and Gianquinto, G. (2012) Low Stomatal Density and Reduced Transpiration Facilitate Strawberry Adaptation to Salinity. Environmental and Experimental Botany, 81, 1-10. https://doi.org/10.1016/j.envexpbot.2012.02.005

[21] Gindel, I. (1969) Stomatal Number and Size as Related to Soil Moisture in Tree Xerophytes in Israel. Ecology, 50, 263-267. https://doi.org/10.2307/1934854

[22] Hetherington, A.M. and Woodward, F.I. (2003) The Role of Stomata in Sensing and Driving Environmental Change. Nature, 424, 901-908.

https://doi.org/10.1038/nature01843

[23] Galmés, J., Flexas, J., Savé, R. and Medrano, H. (2007) Water Relations and Stomatal Characteristics of Mediterranean Plants with Different Growth Forms and Leaf Habits: Responses to Water Stress and Recovery. Plant and Soil, 290, 139-155. https://doi.org/10.1007/s11104-006-9148-6

[24] Gillison, A.N. (2016) Vegetation Functional Types and Traits at Multiple Scales, Vegetation Functional Types and Traits at Multiple Scales. Springer International Publishing, Berlin, 53-97.

[25] McGill, B.J. (2008) Exploring Predictions of Abundance from Body Mass Using Hierarchical Comparative Approaches. The American Naturalist, 172, 88-101. https://doi.org/10.1086/588044

[26] Ross, M.S., O’Brien, J.J. and Flynn, L.J. (1992) Ecological Site Classification of Florida Keys Terrestrial Habitats. Biotropica, 24, 488-502. https://doi.org/10.2307/2389011

[27] Hilu, K.W. and Randall, J.L. (1984) Convenient Method for Studying Grass Leaf Epidermis. Taxon, 33, 413-415. https://doi.org/10.2307/1220980

[28] Rasband, W. (2012) ImageJ 1997-2012.

[29] Vialet-Chabrand, S.R. and Brendel, O. (2014) Automatic Measurement of Stomatal Density from Microphotographs. Trees, 28, 1859-1865. https://doi.org/10.1007/s00468-014-1063-5

[30] Xu, Z. and Zhou, G. (2008) Responses of Leaf Stomatal Density to Water Status and Its Relationship with Photosynthesis in a Grass. Journal of Experimental Botany, 59, 3317-3325. https://doi.org/10.1093/jxb/ern185

[31] Maherali, H., Reid, C.D., Polley, H.W., Johnson, H.B. and Jackson, R.B. (2002) Stomatal Acclimation over a Subambient to Elevated $\mathrm{CO}_{2}$ Gradient in a C3/C4 Grassland. Plant Cell and Environment, 25, 557-566. https://doi.org/10.1046/j.1365-3040.2002.00832.x

[32] Farquhar, G.D., Ehleringer, R. and Hubic, K.T. (1989) Carbon Isotope Discrimination and Photosynthesis. Annual Review of Plant Biology, 40, 503-537. https://doi.org/10.1146/annurev.pp.40.060189.002443 
[33] Team, R.D.C. (2015) R: A Language and Environment for Statistical Computing. R Foundation for Statistical Computing 1, 409.

[34] Sah, J.P., Ross, M.S., Snyder, J.R., Koptur, S. and Cooley, H.C. (2006) Fuel Loads, Fire Regimes, and Post-Fire Fuel Dynamics in Florida Keys Pine Forests. International Journal of Wildland Fire, 15, 463-478. https://doi.org/10.1071/WF05100

[35] Keddy, P.A. (2001) Competition. 1-51.

[36] Griffiths, M.E. and Orians, C.M. (2003) Salt Spray Differentially Affects Water Status, Necrosis, and Growth in Coastal Sandplain Heathland Species. American Journal of Botany, 90, 1188-1196. https://doi.org/10.3732/ajb.90.8.1188

[37] Dunlap, J.M. and Stettler, R.F. (2001) Variation in Leaf Epidermal and Stomatal Traits of Populus trichocarpa from Two Transects across the Washington Cascades. Canadian Journal of Botany, 79, 528-536. https://doi.org/10.1139/b01-029

[38] Abbruzzese, G., et al. (2009) Leaf Morphological Plasticity and Stomatal Conductance in Three Populus alba L. Genotypes Subjected to Salt Stress. Environmental and Experimental Botany, 66, 381-388.

https://doi.org/10.1016/j.envexpbot.2009.04.008

[39] McDowell, N., Bond, B.J., Dickman, L.T., Ryan, M.G. and Whitehead, D. (2011) Relationships between Tree Height and Carbon Isotope Discrimination. In: Meinzer, F.C., Dawson, T.E. and Lachenbruch, B., Eds., Size- and Age-Related Changes in Tree Structure and Function, Springer, New York, 255-286.

[40] Schoch, P.G., Jacques, R., Lecharny, A. and Sibi, M. (1984) Dependence of the Stomatal Index on Environmental-Factors during Stomatal Differentiation in Leaves of Vigna sinensis L. 2. Effect of Different Light Quality. Journal of Experimental Bota$n y, 35,1405-1409$. https://doi.org/10.1093/jxb/35.10.1405

[41] Casson, S.A., Franklin, K.A., Gray, J.E., Grierson, C.S., Whitelam, G.C. and Hetherington, A.M. (2009) Phytochrome B and PIF4 Regulate Stomatal Development in Response to Light Quantity. Current Biology, 19, 229-234.

https://doi.org/10.1016/j.cub.2008.12.046

[42] Haworth, M., Elliott-Kingston, C. and McElwain, J.C. (2011) Stomatal Control as a Driver of Plant Evolution. Journal of Experimental Botany, 62, 2419-2423. https://doi.org/10.1093/jxb/err086

[43] Beerling, D.J. and Chaloner, W.G. (1993) Evolutionary Responses of Stomatal Density to Global $\mathrm{CO}_{2}$ Change. Biological Journal of the Linnean Society, 48, 343-353. https://doi.org/10.1111/j.1095-8312.1993.tb02096.x

[44] Ceulemans, R., Van Praet, L. and Jiang, X.N. (1995) Effects of $\mathrm{CO}_{2}$ Enrichment, Leaf Position and Clone on Stomatal Index and Epidermal Cell Density in Poplar (Populus). New Phytologist, 131, 99-107. https://doi.org/10.1111/j.1469-8137.1995.tb03059.x

[45] Cunningham, S.A., Summerhayes, B. and Westoby, M. (1999) Evolutionary Divergences in Leaf Structure and Chemistry, Comparing Rainfall and Soil Nutrient Gradients. Ecological Monographs, 69, 569-588. https://doi.org/10.1890/0012-9615(1999)069[0569:EDILSA]2.0.CO;2

[46] Fonseca, C.R., Overton, J.McC., Collins, B. and Westoby, M. (2000) Shifts in Trait-Combinations along Rainfall and Phosphorus Gradients. Journal of Ecology, 88, 964-977. https://doi.org/10.1046/j.1365-2745.2000.00506.x

[47] Lee, D.W., et al. (2000) Effects of Irradiance and Spectral Quality on Leaf Structure and Function in Seedlings of Two Southeast Asian Hopea (Dipterocarpaceae) Species. American Journal of Botany, 87, 447-455. https://doi.org/10.2307/2656588 
[48] Schurr, U., Heckenberger, U., Herdel, K., Walter, A. and Feil, R. (2000) Leaf Development in Ricinus communis during Drought Stress: Dynamics of Growth Processes, of Cellular Structure and of Sink-Source Transition. Journal of Experimental Botany, 51, 1515-1529. https://doi.org/10.1093/jexbot/51.350.1515

[49] Subedi, S.C. (2017) A Functional Trait Approach to Examine Plant Community Dynamics in South Florida Hardwood Hammock Forests. PhD Dissertation, Florida International University, Miami.

[50] Franks, P.J. and Farquhar, G.D. (2001) The Effect of Exogenous Abscisic Acid on Stomatal Development, Stomatal Mechanics, and Leaf Gas Exchange in Tradescantia virginiana. Plant Physiology, 125, 935-942. https://doi.org/10.1104/pp.125.2.935

[51] Uprety, D.C., Dwivedi, N., Jain, V. and Mohan, R. (2002) Effect of Elevated Carbon Dioxide Concentration on the Stomatal Parameters of Rice Cultivars. Photosynthetica, 40, 315-319. https://doi.org/10.1023/A:1021322513770

[52] Aasamaa, K., Sober, A. and Rahi, M. (2001) Leaf Anatomical Characteristics Associated with Shoot Hydraulic Conductance, Stomatal Conductance and Stomatal Sensitivity to Changes of Leaf Water Status in Temperate Deciduous Trees. Functional Plant Biology, 28, 765-774. https://doi.org/10.1071/PP00157

[53] Drake, P.L., Froend, R.H. and Franks, P.J. (2013) Smaller, Faster Stomata: Scaling of Stomatal Size, Rate of Response, and Stomatal Conductance. Journal of Experimental Botany, 64, 495-505. https://doi.org/10.1093/jxb/ers347

[54] Ross, M.S., Coultas, C.L. and Hsieh, Y.P. (2003) Soil-Productivity Relationships and Organic Matter Turnover in Dry Tropical Forests of the Florida Keys. Plant and Soil, 253, 479-492. https://doi.org/10.1023/A:1024843130866

[55] Valladares, F., Wright, S.J., Lasso, E., Kitajima, K. and Pearcy, R.W. (2000) Plastic Phenotypic Response to Light of 16 Congeneric Shrubs from a Panamanian Rainforest. Ecology, 81, 1925-1936. https://doi.org/10.1890/0012-9658(2000)081[1925:PPRTLO]2.0.CO;2

[56] Sternberg, L.d.S.L. and Swart, P.K. (1987) Utilization of Freshwater and Ocean Water by Coastal Plants of Southern Florida. Ecology, 68, 1898-1905. https://doi.org/10.2307/1939881

[57] Valladares, F., Gianoli, E. and Gómez, J.M. (2007) Ecological Limits to Plant Phenotypic Plasticity. New Phytologist, 176, 749-763. https://doi.org/10.1111/j.1469-8137.2007.02275.x 
Supplementary Table 1. B. simaruba and its associated species in North Key Largo and their leaf $\delta^{13} \mathrm{C}$. Canopy position are assigned as, canopy tree "C", sub-canopy tree "SC", and understory "U". Canopy trees are highlighted.

\begin{tabular}{|c|c|c|c|c|c|}
\hline SN & $\mathrm{Sp}$ & $\begin{array}{l}\text { Canopy } \\
\text { position }\end{array}$ & Height (m) & $\begin{array}{l}\text { DBH } \\
(\mathrm{cm})\end{array}$ & $\begin{array}{l}\text { Leaf } \\
\delta^{13} \mathrm{C}\end{array}$ \\
\hline 1 & Amyris elemifera $\mathrm{L}$. & SC & 10.5 & 16.0 & -29.55 \\
\hline 2 & Ardisia escallonioides Schltdl. \& Cham. & $\mathrm{U}$ & 4.5 & 5.0 & -31.21 \\
\hline 3 & Ateramnus lucidu (Sw.) Rothm. & SC & 9.8 & 11.9 & -29.34 \\
\hline 4 & Bourreria ovata Miers. & SC & 11.4 & 19.8 & -29.16 \\
\hline 5 & Bursera simaruba (L.) Sarg. & $\mathrm{C}$ & 15.1 & 54.9 & -27.69 \\
\hline 6 & Calyptranthes pallens (Poir.) Griseb. & $\mathrm{U}$ & 8.9 & 11.5 & -31.69 \\
\hline 7 & Coccoloba diversifolia Jacq. & SC & 12.9 & 24.4 & -30.59 \\
\hline 8 & Drypetes diversifolia Krug \& Urb. & SC & 10.8 & 26.5 & -29.38 \\
\hline 9 & Drypetes lateriflora (Sw.) Krug \& Urb. & SC & 10.3 & 13.7 & -31.41 \\
\hline 10 & Eugenia axillaris (Sw.) Willd. & $\mathrm{U}$ & 8.3 & 10.4 & -30.89 \\
\hline 11 & Eugenia foetida Pers. & $\mathrm{U}$ & 4.6 & 2.9 & -30.05 \\
\hline 12 & Ficus citrifolia Mills. & $\mathrm{C}$ & 12.2 & 29.5 & -26.92 \\
\hline 13 & Guapira discolor (Spreng.) Little & $\mathrm{C}$ & 9.6 & 12.8 & -27.34 \\
\hline 14 & Guettarda elliptica Sw. & $\mathrm{U}$ & 7.6 & 6.3 & -30.62 \\
\hline 15 & Guettarda scabra (L.) Vent. & $\mathrm{U}$ & 8.3 & 5.0 & -29.65 \\
\hline 16 & Krugiodendron ferreum (Vahl) Urban & SC & 10.9 & 25.9 & -30.51 \\
\hline 17 & Lysiloma bahamensis Benth. & $\mathrm{C}$ & 15.4 & 72.3 & -28.65 \\
\hline 18 & $\begin{array}{l}\text { Manilkara jaimiqui (C.Wright ex Griseb.) } \\
\text { Dubard subsp. Emarginata (L.) Cronquist }\end{array}$ & SC & 4.2 & 13.8 & -32.58 \\
\hline 19 & Metopium toxiferum(L.) Krug \& Urban. & $\mathrm{C}$ & 13.7 & 29.6 & -28.30 \\
\hline 20 & Nectandra coriacea (Sw.) Griseb. & $\mathrm{U}$ & 9.9 & 10.1 & -29.89 \\
\hline 21 & Piscidia piscipula (L.) Sarg. & $\mathrm{C}$ & 13.2 & 36.6 & -27.32 \\
\hline 22 & Pithecellobium guadalupense Chapm. & $\mathrm{U}$ & 7.6 & 6.4 & -30.23 \\
\hline 23 & Reynosia septentrionalis Urban & SC & 4.2 & 4.7 & -29.82 \\
\hline 24 & Sideroxylon foetidissimum Jacq. & SC & 11.5 & 35 & -29.82 \\
\hline 25 & Sideroxylon salicifolium C.F. Gaertn. & SC & 11.3 & 22.5 & -30.44 \\
\hline 26 & Simarouba glauca DC. & SC & 12.3 & 27.2 & -27.85 \\
\hline 27 & Swietenia mahagoni (L.) Jacq. & $\mathrm{C}$ & 11.6 & 34.3 & -28.19 \\
\hline 28 & Zanthoxylum fagara (L.) Sarg. & SC & 10.6 & 6.5 & -29.64 \\
\hline
\end{tabular}

